\title{
pH-dependent copper release in acid soils treated with crushed mussel shell
}

\author{
B. Garrido-Rodríguez $\cdot$ D. Fernández-Calviño $・$ J. C. Nóvoa Muñoz $\cdot$ \\ M. Arias-Estévez $\cdot$ M. Díaz-Raviña $\cdot$ E. Álvarez-Rodríguez $\cdot$ \\ M. J. Fernández-Sanjurjo · A. Núñez-Delgado
}

Received: 14 July 2011/Revised: 4 March 2012 / Accepted: 28 October 2012/Published online: 28 February 2013

(C) Islamic Azad University (IAU) 2013

\begin{abstract}
The aim of this study was to assess the influence of $\mathrm{pH}$ on copper mobilization in two copper-rich acid soils (from vineyard and mine) amended with crushed mussel shell. Crushed mussel shell amended soils $\left(0-48 \mathrm{Mg} \mathrm{ha}^{-1}\right)$ were subjected to the effect of several acid and alkali solutions in a batch experiment in order to study their copper release. Copper distribution was studied in decanted soils from batch experiments using a sequential extraction procedure, whereas the effect of crushed mussel shell on copper release kinetics was studied using a stirred flow reactor. When soils were treated with acid solutions, the copper mobilization from non-amended soils was significantly higher than from the amended samples. Major
\end{abstract}

B. Garrido-Rodríguez · D. Fernández-Calviño $(\bowtie)$.

J. C. Nóvoa Muñoz · M. Arias-Estévez

Departamento de Bioloxía Vexetal e Ciencia do Solo.

Facultade de Ciencias, Área de Edafoloxía E Química Agrícola,

Universidade de Vigo, Campus de Ourense, As Lagoas s/n,

32004 Ourense, Spain

e-mail: davidfc@uvigo.es

B. Garrido-Rodríguez · D. Fernández-Calviño ·

M. Arias-Estévez

CITI (Centro de Investigación, Transferencia e Innovación).

Universidade de Vigo, Tecnopole, As Lagoas s/n,

32004 San Cibrao das Viñas Ourense, Spain

\section{Díaz-Raviña}

Departamento de Bioquímica del Suelo, Instituto de Investigaciones Agrobiológicas de Galicia (CSIC), Apartado 122. Avda. Vigo s/n,

15780 Santiago de Compostela, Spain

E. Álvarez-Rodríguez · M. J. Fernández-Sanjurjo ·

A. Núñez-Delgado

Departamento de Edafoloxía e Química Agrícola, Universidade Santiago de Compostela. Escola Politécnica

Superior, Campus Universitario s/n, 27002 Lugo, Spain changes in copper fractionation were an increase of the acid soluble fraction in acid-treated vineyard soil samples with shell dose. For the mine soil, the oxidable fraction showed a relevant diminution in acid-treated samples at the highest crushed mussel shell dose. For both soils, copper desorption rates diminished up to $86 \%$ at $\mathrm{pH} 3$ when crushed mussel shell was added. At $\mathrm{pH} 5$, copper release rate was very slow for both soils decreasing up to $98 \%$ for the mine soil amended with the highest shell dose, whereas no differences were observed at $\mathrm{pH} 7$ between amended and non-amended soils. Thus, crushed mussel shell addition could contribute to reduce potential hazard of copperenriched soils under acidification events.

Keywords Copper fractionation - Mine soil . Release kinetics · Vineyard

\section{Introduction}

As a result of using fungicides with high copper $(\mathrm{Cu})$ content, this metal usually accumulates in the upper layers of vineyard soils, a process which was favoured by its low mobility (Fernández-Calviño et al. 2008, 2009a). This fact may cause damage to the soil quality and could produce environmental deterioration. Other environments where high $\mathrm{Cu}$ levels can be detected are $\mathrm{Cu}$-exploited mine tailings. The pollution potential of these areas is high, mostly due to the risk of leaching pollutants to the watercourses in the nearby zone. These leachates may contain high $\mathrm{Cu}$ levels, as well as high acidity (Álvarez et al. 2011).

In recent years, low-cost materials were used as sustainable bioadsorbent for the removal of toxic metals (Bailey et al. 1999; Zvinowanda et al. 2009; Dizadji et al. 2011); however, the mussel shell was scarcely tested. 
Galicia (NW Spain) is one of the most important producers of mussel (Mytilus galloprovincialis) in the world (Caballero et al. 2009). Most of this mussel production is processed by the cannery industry generating great amounts of wastes (mainly mussel shells), which will vary between 65,682 and 93,541 tonnes per year depending on mussel production (Barros et al. 2009; Peña-Rodríguez et al. 2010). In coastal areas, it is traditional that farmers helped to the direct recycling of untreated shell using it to increase the $\mathrm{pH}$ of acid soils. However, in the last decades some factories have implemented industrial processes leading to the treatment of waste shells, in order to transform it into products rich in carbonates and oxides with an appropriate particle size and without residual organic matter. These factories are engaged in different processes including particularly washing, crushing (and also calcination in some factories) and finally sieving of the treated shells.

Regarding the effects of mussel shell on the retention and releasing of certain substances, it was shown that the degree of retention of divalent cations in the shell is higher when it contains more aragonite than calcite (Prieto et al. 2003; Cubillas et al. 2005a; Köhler et al. 2007; Sakulkhaemaruethai et al. 2010). The shell of some species is mainly constituted by aragonite, and only after calcination it showed a higher percentage of calcite (Currie et al. 2007; Abeynaike et al. 2011). Other species may have shells that originally contain higher percentage of calcite, or even high levels of both $\mathrm{CaCO}_{3}$ polymorphs (Cubillas et al. $2005 \mathrm{a}, \mathrm{b})$. The adsorption of dissolved $\mathrm{Cu}$ and $\mathrm{Zn}$ was studied by Kitano et al. (1976) showing clear differences between calcite and aragonite. Focusing on other divalent cations, Prieto et al. (2003) showed positive results as regards $\mathrm{Cd}^{2+}$ retention in aragonite by means of cockle shell showing as well that retention was clearly lower when using calcite. The same higher retention of $\mathrm{Cd}^{2+}$ in aragonite was reported by Cubillas et al. (2005b), this time using mussel shell and also shell from other bivalves. The high efficacy of aragonite in the retention of dissolved $\mathrm{Cd}^{2+}, \mathrm{Pb}^{2+}$ and $\mathrm{Zn}^{2+}$ was reported by Köhler et al. (2007), whereas high levels of $\mathrm{Hg}^{2+}$ could be retained using calcined mussel shell, but this material contained $7 \%$ of aragonite even after calcination (Peña-Rodríguez et al. 2010).

The aims of this study were to assess the effects of the amendment of two $\mathrm{Cu}$-enriched soils, a vineyard soil and a soil from a $\mathrm{Cu}$-mine tailing, with crushed mussel shell (CMS) on the pH-dependent release and the kinetic characteristics of copper release. In addition, changes in $\mathrm{Cu}$ distribution in soil residues amended and non-amended with CMS after acid and alkali treatments were also assessed. Since CMS contains $44 \%$ aragonite, a high potential for $\mathrm{Cu}^{2+}$ retention could be expected. This research was conducted at the laboratories of soil science of the universities of Vigo and Santiago de Compostela and in the laboratory of soil biochemistry of the Agrobiological Research Institute of Galicia (Spain) during 2010.

\section{Materials and methods}

\section{Soil characteristics}

The surface layer of two soil types $(0-20 \mathrm{~cm})$ was sampled in a vineyard area (A) and in a copper mine tailing (B), both located in NW Spain. Both soil samples were airdried, sieved through 2-mm sieve and then stored until being analysed.

The $\mathrm{pH}$ in water and in $0.1 \mathrm{M} \mathrm{KCl}$ was measured with a combined glass electrode using a 1:2.5 (soil:water) ratio. Total carbon and nitrogen contents were determined by elemental analysis using a Thermo Finnigan 1112 Series $\mathrm{NC}$ elemental analyser. The particle size distribution was determined by the wet sieving and pipette methods according to Gee and Bauder (1986). The effective cation exchange capacity (eCEC) was estimated as the sum of base cations ( $\mathrm{Na}, \mathrm{K}, \mathrm{Ca}, \mathrm{Mg})$ extracted with $0.2 \mathrm{M} \mathrm{NH}_{4} \mathrm{Cl}$ (Sumner and Miller 1996) and Al extracted with $1 \mathrm{M} \mathrm{KCl}$ (Bertsch and Bloom 1996). Base cations and $\mathrm{Al}$ were determined by emission ( $\mathrm{Na}$ and $\mathrm{K}$ ) or flame atomic absorption spectrophotometry, with a Thermo Solaar M Series spectrophotometer. The total contents of $\mathrm{Ca}\left(\mathrm{Ca}_{\mathrm{T}}\right)$ and $\mathrm{Al}\left(\mathrm{Al}_{\mathrm{T}}\right)$ were determined by ICP-OES after digestion of $0.5 \mathrm{~g}$ of finely ground soil sample with a mixture of concentrated strong acids $\left(5 \mathrm{~mL} \quad \mathrm{HNO}_{3}+4 \mathrm{~mL}\right.$ $\mathrm{HF}+1 \mathrm{~mL} \mathrm{HCl}$ ) in a microwave oven (ETHOS 900 Microwave Labstation). General characteristics of both soils are shown in Table 1.

\section{Crushed mussel shell (CMS) and soil/CMS mixtures}

The crushed mussel shell samples were from Abonomar S.L. (Illa de Arousa, Pontevedra, Spain), and its general characteristics are shown in Table 1. The aragonite and calcite contents of the shells used in this study were determined by X-ray diffraction analysis (Philips PW1710 Difractometer), being 44 and $48 \%$, respectively. The content of both polymorphs is high.

To carry out the present study, various mixtures of CMS and soils (soil A or soil B) were performed. Considering an effective soil depth of $20 \mathrm{~cm}$ and a soil bulk density of $1 \mathrm{~g} \mathrm{~cm}^{-3}, 400 \mathrm{~g}$ of soil A or soil B was mixed with different amounts of CMS to obtain final doses of 0, 12, 24 and $48 \mathrm{Mg} \mathrm{ha}^{-1}$ of CMS (which correspond to the addition of $0,6,12$ and $24 \mathrm{~g}$ of CMS per kg of soil, respectively). 
Table 1 General characteristics of the vineyard soil (soil A), the mine soil (soil B) and the crushed mussel shell (CMS)

\begin{tabular}{llclllllllrr}
\hline Sample & Sand (\%) & Silt (\%) & Clay (\%) & $\mathrm{pH}\left(\mathrm{H}_{2} \mathrm{O}\right)$ & $\mathrm{pH}(\mathrm{KCl})$ & $\mathrm{C}_{\mathrm{T}}(\%)$ & $\mathrm{N}(\%)$ & $\begin{array}{l}\mathrm{eCEC} \\
\left(\mathrm{cmol} \mathrm{kg}^{-1}\right)\end{array}$ & $\begin{array}{l}\mathrm{Cu}_{\mathrm{T}} \\
\left(\mathrm{mg} \mathrm{kg}^{-1}\right)\end{array}$ & $\begin{array}{c}\mathrm{Ca}_{\mathrm{T}}(\%) \\
\mathrm{Al}_{\mathrm{T}}(\%)\end{array}$ \\
\hline Soil A & 73.4 & 12.0 & 14.6 & 4.5 & 3.5 & 2.6 & 0.17 & 5.30 & 361 & 0.06 \\
Soil B & 67.4 & 14.0 & 18.6 & 3.8 & 3.0 & 0.3 & 0.04 & 3.89 & 651 & 0.06 & 0.96 \\
CMS & 99.5 & 0.3 & 0.1 & 9.4 & 9.0 & 12.4 & 0.08 & 30.30 & 9 & 36.4 & 0.3 \\
\hline
\end{tabular}

In order to facilitate a better homogenization of the mixtures, they were shaken end-over-end for $72 \mathrm{~h}$ in $2 \mathrm{~L}$ polypropylene bottles. After shaking, all mixtures were passed at least five times for a Retsch homogenizer, and then they were stored until further use.

$\mathrm{pH}$-dependent $\mathrm{Cu}, \mathrm{Ca}$ and $\mathrm{Al}$ release

The following experiment was performed to assess the effect of CMS addition on $\mathrm{Cu}$ release in a wide range of $\mathrm{pH}$ values. Thus, $10 \mathrm{~mL}$ of various $\mathrm{HNO}_{3}$ solutions $(0.02$, $0.015,0.01,0.0075$ and $0.005 \mathrm{M})$ or $\mathrm{NaOH}$ solutions $(0.02$, $0.015,0.01,0.0075$ and $0.005 \mathrm{M}$ ) were added to a $1 \mathrm{~g}$ of mixture. All solutions (acid and alkali) contained $0.05 \mathrm{M}$ $\mathrm{NaNO}_{3}$ as background electrolyte. In addition, $0.05 \mathrm{M}$ $\mathrm{NaNO}_{3}$ solution was also used as a control (no acid or base added). The resulting suspensions were shaken for $24 \mathrm{~h}$ and afterwards centrifuged at 4,000 rpm for $5 \mathrm{~min}$. The supernatant was filtered through acid washed paper and then $\mathrm{pH}$ was measured by means of a glass electrode, whereas $\mathrm{Cu}, \mathrm{Ca}$ and $\mathrm{Al}$ concentrations were determined by atomic absorption spectrophotometry, with a Thermo Solaar M Series spectrophotometer.

\section{Copper fractionation}

Soil residues precipitated after centrifuging from $0.02 \mathrm{M}$ $\mathrm{HNO}_{3}$, no acid or base added $\left(0.05 \mathrm{M} \mathrm{NaNO}_{3}\right)$ and $0.02 \mathrm{M}$ $\mathrm{NaOH}$ treatments were selected to asses the effects of $\mathrm{pH}$ treatments and CMS addition in $\mathrm{Cu}$ distribution. Soil residues were washed with $30 \mathrm{~mL}$ of $0.05 \mathrm{M} \mathrm{NaNO}_{3}$ solution and then centrifuged at 4,000 rpm for $5 \mathrm{~min}$ to remove the excess acid or base. This wash step was repeated twice and afterwards soil residues were oven dried at $30-35^{\circ} \mathrm{C}$ and homogenized. Copper distribution was studied in soil residues according to the BCR method (Ure et al. 1993; Rauret et al. 1999). BCR method is a sequential extraction procedure consisting in four steps in which the following reagents are used: $0.11 \mathrm{M}$ acetic acid, hydroxylamine chlorhydrate solution (acidified to $\mathrm{pH} 2$ with $\mathrm{HNO}_{3}$ ), $30 \%$ $\mathrm{H}_{2} \mathrm{O}_{2}$ solution and $3 \mathrm{~mL} \mathrm{HNO}_{3}{ }^{+} 9 \mathrm{~mL} \mathrm{HCl}$ digestion in a microwave oven. After the application of each reagent a washing step, consisting in washing the soil residue with
$30 \mathrm{~mL}$ of $0.05 \mathrm{M} \mathrm{NaNO}$ solution, then centrifuging (4,000 rpm for $5 \mathrm{~min}$ ) and finally removing the supernatant, was carried out in triplicate. This sequential extraction procedure gives the following $\mathrm{Cu}$ fractions: acid soluble fraction (ASF), reducible fraction (RF), oxidable fraction (OF) and the residual fraction (REF). Thus, $\mathrm{Cu}$ in ASF fraction is assumed to be derived from cationic exchange sites of soil colloids, as well as $\mathrm{Cu}$ associated with carbonates. Copper in RF is assumed to be associated with $\mathrm{Fe}$ and $\mathrm{Al}$ oxides and oxyhydroxides, whereas OF estimates $\mathrm{Cu}$ bound to soil organic matter and its presence as sulphides. Finally, REF is supposedly a mixture of the most recalcitrant $\mathrm{Cu}$ forms in the soil.

In all soil extracts, copper was measured by atomic absorption spectrophotometry, with a Thermo Solaar M Series spectrophotometer.

\section{Kinetics of $\mathrm{Cu}$ release}

We performed stirred flow reactor experiments in order to study the effect of the addition of CMS on $\mathrm{Cu}$ releasing kinetics. We carried out experiments with samples from both soils without CMS addition (control) and with a CMS addition of $48 \mathrm{Mg} \mathrm{ha}^{-1}$. The experiments were performed at three different $\mathrm{pH}$ values of the inflow solution $(3,5$ and 7). The polypropylene stirred flow reactor $\left(1.5 \mathrm{~cm}^{3}\right)$ was the same used in a previous study by Fernández-Calviño et al. (2010a), based on that reported by López-Periago et al. (2008). Tests were performed in a cabinet thermostated at $25.0 \pm 0.1{ }^{\circ} \mathrm{C}$, the flow rate was $0.6 \mathrm{~mL} \mathrm{~min}^{-1}$ and one vial was collected each $2.5 \mathrm{~min}$ during $200 \mathrm{~min}$.

The experiments were carried out as follows: $0.2 \mathrm{~g}$ of sample was placed together with a magnetic stirring bar in the reaction chamber. Solutions with different $\mathrm{pH}$ values (3, 5 and 7) were circulated at the selected flow rate with $0.01 \mathrm{M} \mathrm{NaNO}_{3}$ solution as background electrolyte. In total, 80 samples of $1.5 \mathrm{~mL}$ were collected in different vials (all filled in $2.5 \mathrm{~min}$ each) in which $\mathrm{Cu}$ was determined by atomic absorption spectrophotometry, with a Thermo Solaar M Series spectrophotometer.

The $\mathrm{Cu}$ released from the soil samples $(q(i))$ at time $i \Delta t$ (where $\Delta t$ is the time taken to collect each effluent sample) was calculated, following Yin et al. (1997), from 


$$
\begin{aligned}
q(i) & =\left\{\sum_{j=1}^{i}\left[\frac{\left(C_{1}(j)-C_{2}(j)\right) \Delta t J_{\mathrm{w}}}{\mathrm{Ve}}\right]\right. \\
& \left.+\left[C_{1}(i+1)-C_{2}(i+1)\right]\right\} \frac{\mathrm{Ve}}{m}
\end{aligned}
$$

where $C_{1}(i)$ and $C_{2}(i)$ are the concentrations of metal in the $i$ th effluent sample in the absence and presence of sample, respectively, $\mathrm{Ve}$ is the effective volume of solution in the reactor, $J_{\mathrm{w}}$ is the flow rate $\left(0.6 \mathrm{~mL} \mathrm{~min}{ }^{-1}\right)$ and $\mathrm{m}$ is the mass of the soil sample. $\mathrm{Cu}$ released rates $(V(i))$ were calculated as follows:

$V(i)=\frac{q(i+\Delta t)-q(i)}{\Delta t}$

\section{Results and discussion}

Effects of CMS addition on $\mathrm{pH}$ and on $\mathrm{Ca}, \mathrm{Cu}$ and $\mathrm{Al}$ release from amended soils

Figure 1 showed the variation of $\mathrm{pH}$ values as a function of the amount of acid or base added to the soil/CMS mixtures. This figure indicates that the buffer potential of the soils increases with the CMS dose. Under near-neutral $\mathrm{pH}$ conditions (no acid or alkali addition), the buffer effect promoted by CMS addition to the vineyard soil (A) caused a $\mathrm{pH}$ increase that ranges from 4.8 (no CMS addition) to 7.5 when $48 \mathrm{Mg} \mathrm{ha}^{-1}$ CMS was added (Fig. 1). In the mine soil, the addition of $48 \mathrm{Mg} \mathrm{ha}^{-1} \mathrm{CMS}$ resulted in a $\mathrm{pH}$ increase from 4.0 (no acid or alkali addition) to 7.3 (Fig. 1). However, the buffer effects associated with CMS addition are higher after the application of acid solutions than after applying alkali solutions. Thus, after the treatment of vineyard soil samples with $0.02 \mathrm{M} \mathrm{HNO}_{3}$ solution, the $\mathrm{pH}$ value changed in 4.5 units comparing to no CMS addition and to $48 \mathrm{Mg} \mathrm{ha}^{-1} \mathrm{CMS}$ amendment (2.6-7.1), while this difference was only 0.4 units $(8.5-8.9)$ when the treatment was $0.02 \mathrm{M} \mathrm{NaOH}$ (Fig. 1). The behaviour of the mine soil (B) is similar to soil A at the $0.02 \mathrm{M} \mathrm{HNO}_{3}$ treatment, showing the same variation in terms of $\mathrm{pH}$ units (4.4) but a different range of $\mathrm{pH}$ values, from 2.2 without CMS addition to 6.6 after the addition of $48 \mathrm{Mg} \mathrm{ha}^{-1} \mathrm{CMS}$ (Fig. 1). Nevertheless, the buffer potential of soil $\mathrm{B}$ is higher than that of soil $\mathrm{A}$ at basic $\mathrm{pH}$ values, since $\mathrm{pH}$ difference was only 1.3 units between the control sample (6.7) and the sample with the highest CMS dose (8.0) as was shown in Fig. 1.

These results mean that CMS is suitable to reduce the acidity of these soils, being this application very interesting especially due to its low cost. Thus, CMS addition provides buffer potential to acid soils which avoid drastic $\mathrm{pH}$ changes. As shown in Fig. 1, pH changes were less pronounced after the addition of the highest CMS dose. These changes in soil $\mathrm{pH}$, as an effect of the buffer capacity supplied by CMS addition, are narrowly associated to a marked Ca release due to dissolution of calcium carbonates present in the mussel shell.

The changes in Ca release as function of the amount of acid or alkali added are shown in Fig. 2. When no CMS was added (control), Ca release was always higher in soil $\mathrm{A}$ than in soil $\mathrm{B}$. Under a near-neutral $\mathrm{pH}$ conditions $\left(0.05 \mathrm{M} \mathrm{NaNO}_{3}\right.$ treatment $)$ soil $\mathrm{A}$ released more $\mathrm{Ca}$ $\left(280 \pm 5 \mathrm{mg} \mathrm{kg}^{-1}\right)$ than soil B $\left(128 \pm 2 \mathrm{mg} \mathrm{kg}^{-1}\right)$. However, under the treatment with acid solutions, the release of Ca increases greatly in both soils (Fig. 2) being higher in soil $\mathrm{A}$ (up to $900 \mathrm{mg} \mathrm{kg}^{-1}$ ) than in soil B $\left(200 \mathrm{mg} \mathrm{kg}^{-1}\right)$. In the soil/CMS mixtures, Ca release increased as a function of CMS dose (Fig. 2). Thus, at the highest acid addition $\left(20 \mathrm{cmol} \mathrm{H}+\mathrm{kg}^{-1}\right)$, Ca release was lower in soil A than in soil B $\left(5,077 \mathrm{mg} \mathrm{kg}^{-1}\right.$ vs. $\left.5,687 \mathrm{mg} \mathrm{kg}^{-1}\right)$ when CMS dose was $48 \mathrm{Mg} \mathrm{ha}^{-1}$. Taking into consideration the difference
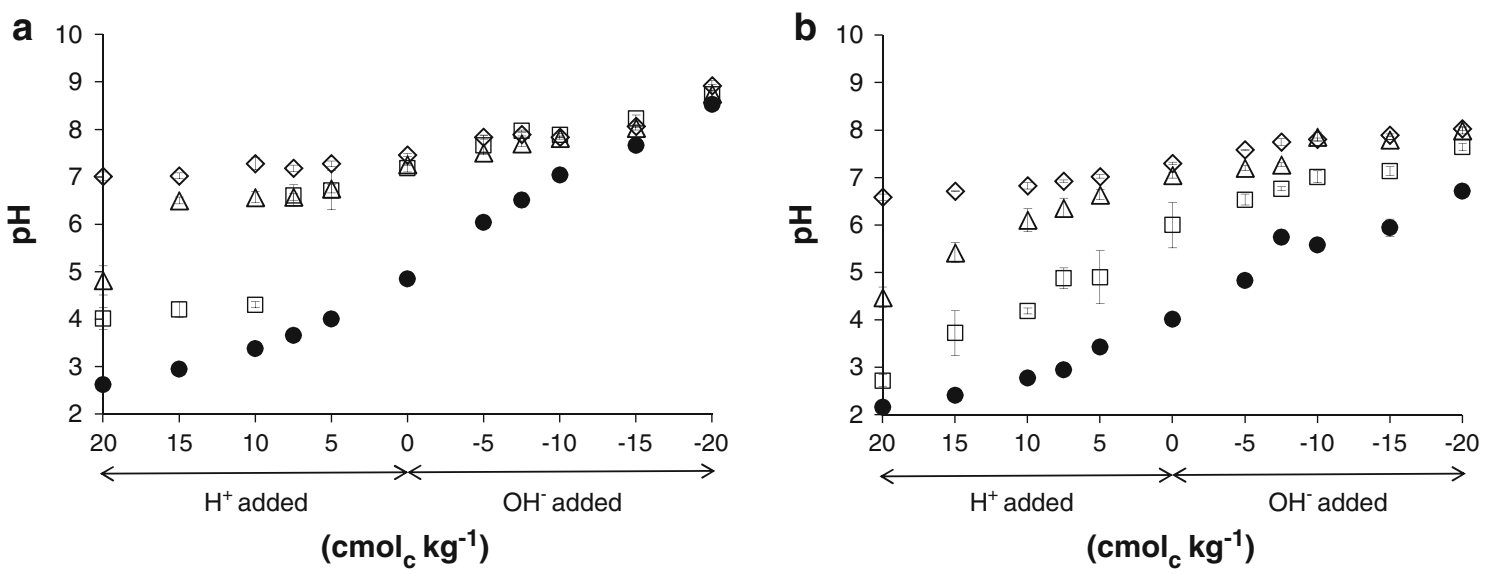

Fig. 1 Changes in $\mathrm{pH}$ values due to the addition of $\mathrm{HNO}_{3}$ or $\mathrm{NaOH}$ solutions to samples of a vineyard soil (a) and mine soil (b) non-amended (filled circles) and amended with 12 (squares), 24 (triangles) and 48 (diamonds) $\mathrm{Mg} \mathrm{ha}^{-1}$ of CMS 

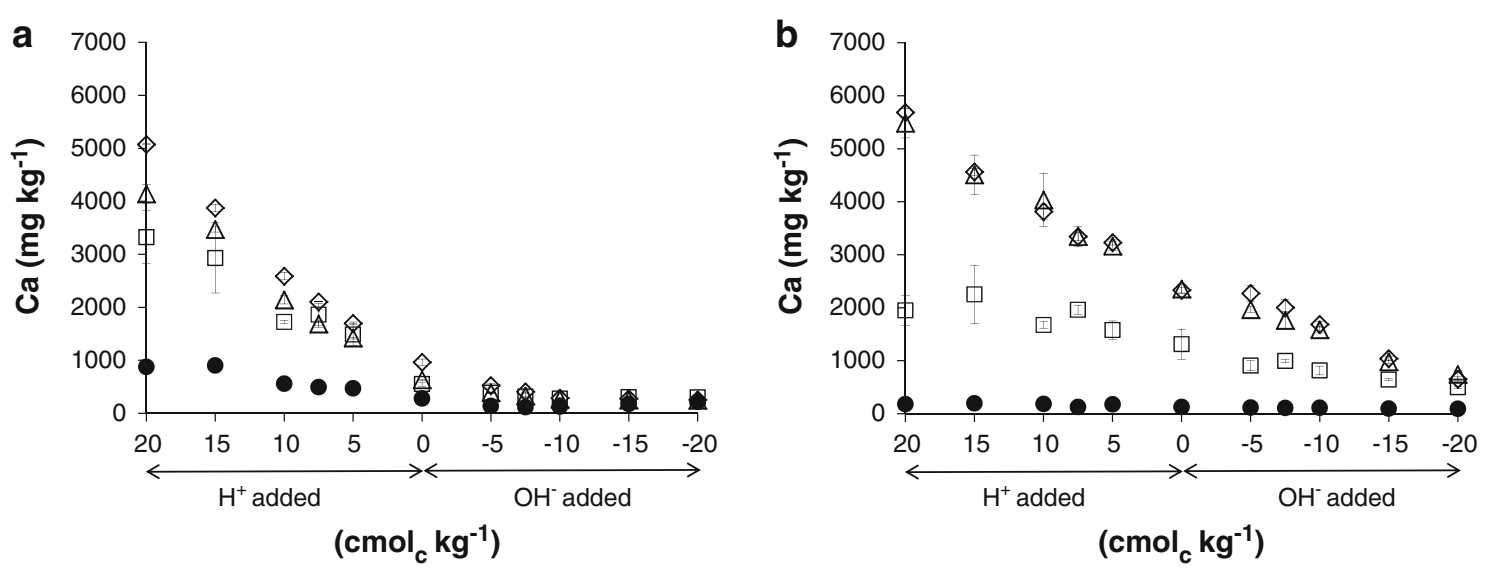

Fig. 2 Changes in Ca release as a function of the addition of $\mathrm{HNO}_{3}$ or $\mathrm{NaOH}$ solutions to samples of a vineyard soil (a) and mine soil (b) nonamended (filled circles) and amended with 12 (squares), 24 (triangles) and 48 (diamonds) $\mathrm{Mg} \mathrm{ha}^{-1}$ of CMS
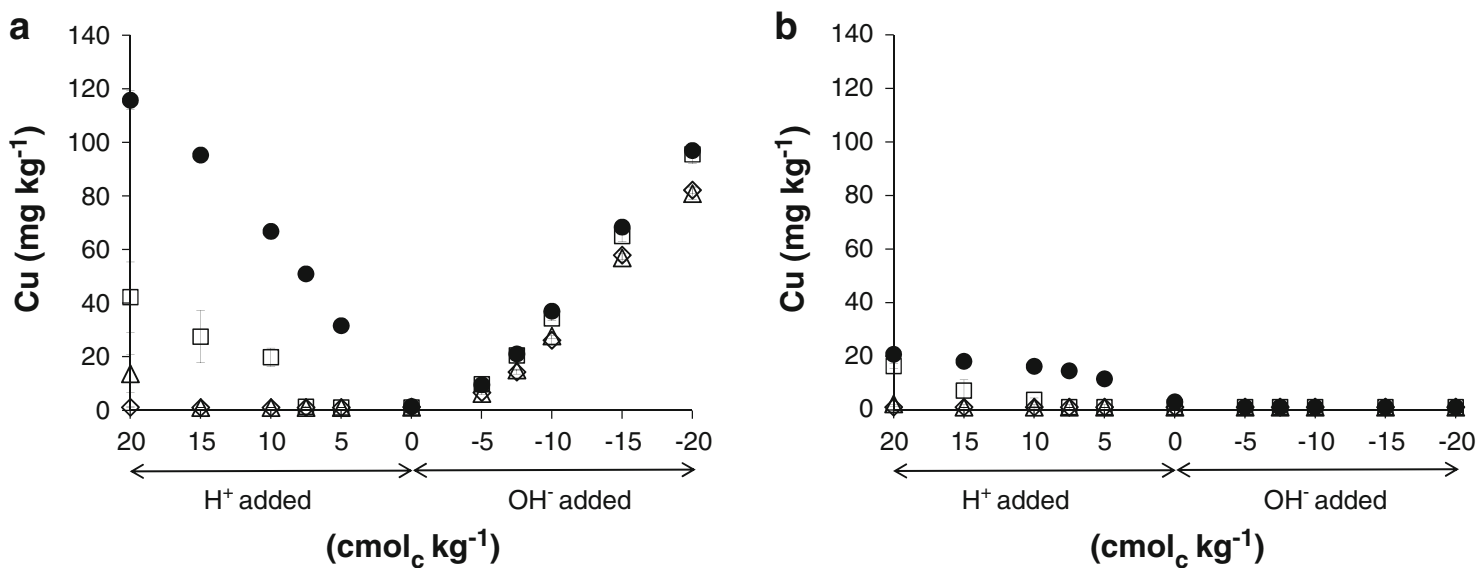

Fig. 3 Changes in $\mathrm{Cu}$ release as a function of the addition of $\mathrm{HNO}_{3}$ or $\mathrm{NaOH}$ solutions to samples of a vineyard soil (a) and mine soil (b) nonamended (filled circles) and amended with 12 (squares), 24 (triangles) and 48 (diamonds) $\mathrm{Mg} \mathrm{ha}^{-1}$ of CMS

between Ca released from the control soil samples and from soils amended with the highest CMS dose, soil A released $4,202 \mathrm{mg} \mathrm{kg}^{-1}$ (48\% of the Ca added with CMS) while soil B released $5,505 \mathrm{mg} \mathrm{kg}^{-1}$ (63\% of the $\mathrm{Ca}$ added with CMS $)$. Under treatment with highest alkali dose $(20 \mathrm{cmol}$ $\mathrm{OH}-\mathrm{kg}^{-1}$ ), a comparison between the amount of $\mathrm{Ca}$ released from control samples and from samples amended with $48 \mathrm{Mg} \mathrm{ha}^{-1}$ of CMS resulted in a lower increase in Ca released at basic $\mathrm{pH}$ values from soil $\mathrm{A}\left(38 \mathrm{mg} \mathrm{kg}^{-1}\right.$, approximately $0.4 \%$ of the $\mathrm{Ca}$ added with CMS) than for soil $\mathrm{B}\left(560 \mathrm{mg} \mathrm{kg}^{-1}\right.$, equivalent to $6.4 \%$ of the $\mathrm{Ca}$ added with CMS) (Fig. 2).

The differences in $\mathrm{Ca}$ release from $\mathrm{CMS} /$ soil $\mathrm{A}$ and CMS/soil B mixtures could depend on their different soil mineralogical composition, with several cations that would interact with calcite and aragonite forming mineral coatings, resulting in contrasting calcite and aragonite dissolution rates (Cubillas et al. 2005a). In this sense,
Cubillas et al. (2005b), studying the effect of $\mathrm{Cd}$ on calcium carbonate dissolution rates, reported that thin coatings on mineral surfaces can reduce significantly their dissolution rates.

Since both vineyard and mine soils here studied had a considerably high $\mathrm{Cu}$ content, the changes in its release depending on the amount of acid or alkali added and CMS addition was shown in Fig. 3. The results obtained revealed that $\mathrm{Cu}$ mobility is highly affected by $\mathrm{pH}$ and thus nonamended vineyard soil samples (A) showed a $\mathrm{Cu}$ release for all $\mathrm{pH}$ range experimented as a $\mathrm{U}$-shaped curve, while control samples of the mine soil (B) only released $\mathrm{Cu}$ at most acid $\mathrm{pH}$ values (Fig. 3). Copper release was higher in soil A (achieving above $100 \mathrm{mg} \mathrm{kg}^{-1}$ as result of the addition of more acid or alkali solutions) than in soil B (up to $21 \mathrm{mg} \mathrm{kg}^{-1}$ of $\mathrm{Cu}$ at the highest acid treatment, but only $1 \mathrm{mg} \mathrm{kg}^{-1} \mathrm{Cu}$ at the highest alkali treatment). These amounts of $\mathrm{Cu}$ released, referred as percentages of total $\mathrm{Cu}$ 
Table 2 Mean and standard error values of percentages of $\mathrm{Cu}$ (referred to total $\mathrm{Cu}$ ) and dissolved organic matter $\left(\mathrm{OM}_{\mathrm{d}}, \mathrm{mg} \mathrm{kg}^{-1}\right)$ released for vineyard soil (A) and mine soil (B) as a function of the amount of acid or base added and the CMS dose $\left(\mathrm{A}_{0}\right.$ and $\mathrm{B}_{0}$ : no CMS; $\mathrm{A}_{12}$ and $\mathrm{B}_{12}: 12 \mathrm{Mg} \mathrm{ha}^{-1}$ of CMS; $\mathrm{A}_{24}$ and $\mathrm{B}_{24}: 24 \mathrm{Mg} \mathrm{ha}^{-1}$ of CMS; $\mathrm{A}_{48}$ and $\mathrm{B}_{48}: 48 \mathrm{Mg} \mathrm{ha}^{-1}$ of CMS)

\begin{tabular}{|c|c|c|c|c|c|c|}
\hline \multirow[t]{3}{*}{ Sample } & \multicolumn{6}{|c|}{ Acid or base added } \\
\hline & \multicolumn{2}{|c|}{$0.02 \mathrm{M} \mathrm{HNO}_{3}$} & \multicolumn{2}{|l|}{ None } & \multicolumn{2}{|c|}{$0.02 \mathrm{M} \mathrm{NaOH}$} \\
\hline & $\mathrm{Cu}(\%)$ & $\mathrm{OM}_{\mathrm{d}}$ & $\mathrm{Cu}(\%)$ & $\mathrm{OM}_{\mathrm{d}}$ & $\mathrm{Cu}(\%)$ & $\mathrm{OM}_{\mathrm{d}}$ \\
\hline \multicolumn{7}{|l|}{ A } \\
\hline $\mathrm{A}_{0}$ & $32.1 \pm 0.8$ & $303 \pm 1$ & $0.4 \pm 0.0$ & $138 \pm 2$ & $26.9 \pm 0.6$ & $14942 \pm 40$ \\
\hline $\mathrm{A}_{12}$ & $11.7 \pm 2.9$ & $166 \pm 9$ & $0.3 \pm 0.0$ & $183 \pm 2$ & $26.5 \pm 0.8$ & $14118 \pm 119$ \\
\hline $\mathrm{A}_{24}$ & $3.8 \pm 1.6$ & $36 \pm 2$ & $0.3 \pm 0.1$ & $43 \pm 2$ & $22.4 \pm 0.5$ & $4494 \pm 210$ \\
\hline $\mathrm{A}_{48}$ & $0.3 \pm 0.1$ & $54 \pm 3$ & $0.3 \pm 0.0$ & $73 \pm 9$ & $22.8 \pm 0.3$ & $4309 \pm 83$ \\
\hline \multicolumn{7}{|l|}{ B } \\
\hline $\mathrm{B}_{0}$ & $3.5 \pm 0.1$ & $27 \pm 6$ & $0.5 \pm 0.0$ & $14 \pm 1$ & $0.2 \pm 0.0$ & $19 \pm 4$ \\
\hline $\mathrm{B}_{12}$ & $2.8 \pm 0.1$ & $25 \pm 1$ & $0.2 \pm 0.0$ & $15 \pm 2$ & $0.2 \pm 0.0$ & $19 \pm 2$ \\
\hline $\mathrm{B}_{24}$ & $0.4 \pm 0.1$ & $8 \pm 2$ & $0.2 \pm 0.0$ & $7 \pm 0$ & $0.2 \pm 0.0$ & $21 \pm 1$ \\
\hline $\mathrm{B}_{48}$ & $0.2 \pm 0.0$ & $11 \pm 1$ & $0.2 \pm 0.0$ & $14 \pm 1$ & $0.2 \pm 0.0$ & $25 \pm 1$ \\
\hline
\end{tabular}

$(\mathrm{CuT})$ are shown in Table 2. The percentage of $\mathrm{Cu}$ releases was one order of magnitude higher in soil A (32 and $27 \%$ of $\mathrm{CuT}$ when $0.02 \mathrm{M}$ of $\mathrm{HNO}_{3}$ or $\mathrm{NaOH}$ solutions were added, respectively) than in soil $\mathrm{B}$ (3.5 and $0.2 \%$ of $\mathrm{CuT}$ when $0.02 \mathrm{M}$ of $\mathrm{HNO}_{3}$ or $\mathrm{NaOH}$ solutions were added, respectively).

The increase in $\mathrm{Cu}$ liberation, both at acid and basic $\mathrm{pH}$ values (U-shaped curve) was due to an increased $\mathrm{Cu}$ solubility at acid $\mathrm{pH}$ values and to the dissolution of organically bound $\mathrm{Cu}$ at basic $\mathrm{pH}$ values (Fernández-Calviño et al. 2008). This last hypothesis is consistent with the observed increase in the liberation of dissolved organic matter (OMd) at basic pH (Table 2).

Regarding the differences in $\mathrm{Cu}$ release from both soils, Fernández-Calviño et al. (2009b) found a similar response when compared vineyard soils and corn-cropping soils, with U-shaped $\mathrm{Cu}$ release curves in the vineyard soils, and with the corn-cropping soils behaving as the mine soil in this study. These authors attributed this different behaviour to the different origin of the copper in both soils, being mainly anthropogenic in the vineyard soils and derived from lithology in the corn-cropping soils. This explanation could be also applied in the present study, being the $\mathrm{Cu}$ from the vineyard soil mainly anthropogenic (due to application of copper-based fungicides), while the $\mathrm{Cu}$ in the mine soil is attributed to the presence of minerals with high copper content inherited from the parent material (mainly chalcopyrite).

Crushed mussel shell additions diminished clearly the amount of $\mathrm{Cu}$ released from both soils under acid conditions (Fig. 3). Thus, when $0.02 \mathrm{M} \mathrm{HNO}_{3}$ solution was added, $\mathrm{Cu}$ liberation diminished from $100 \mathrm{mg} \mathrm{kg}^{-1}$ in non- amended soil A to about $1 \mathrm{mg} \mathrm{kg}^{-1}$ when soil $\mathrm{A}$ was mixed with CMS at dose of $48 \mathrm{Mg} \mathrm{ha}^{-1}$. Under the same acid treatment, $\mathrm{Cu}$ liberation from soil $\mathrm{B}$ diminished from $21 \mathrm{mg} \mathrm{kg}^{-1}$ when no CMS was added till near $1 \mathrm{mg} \mathrm{kg}^{-1}$ after the addition of $48 \mathrm{Mg} \mathrm{ha}^{-1} \mathrm{CMS}$. These values of diminution of $\mathrm{Cu}$ release, expressed as percentage of $\mathrm{CuT}$, were shown in Table 2. As opposite to acid treatments, when soils were treated with alkali solutions, the effect of CMS addition in the diminution of $\mathrm{Cu}$ liberation was very low in both soils (Fig. 3).

The results of $\mathrm{Cu}$ liberation revealed that the addition of CMS may be used to immobilize $\mathrm{Cu}$ in a broad range of $\mathrm{pH}$ values. However, the CMS addition drastically diminished $\mathrm{Cu}$ release in both soils even when they were exposed to high acid loads, especially at the highest CMS doses (Fig. 3). This diminution in $\mathrm{Cu}$ release was mainly due to the additional buffer potential provided by CMS to the soils, but also due to its expected faster dissolution rate, when compared with typical soil compounds responsible for neutralization in acid soils, such as alumino-silicates and metal (Al, Fe)-humus complexes (Simonsson and Berggern 1998; Yagasaki et al. 2006; Nóvoa-Muñoz and García-Rodeja 2007). The effect of the CMS dose on $\mathrm{Cu}$ release would be partially related to its aragonite/calcite contents (44 and $48 \%$, respectively). Kitano et al. (1976), studying the adsorption of copper ions on calcite and aragonite, reported that $\mathrm{Cu}$ ions were removed completely through its adsorption on aragonite.

Aluminium release showed a similar behaviour to that of $\mathrm{Cu}$, with a U-shaped curve for its liberation from nonamended samples of soil A, suggesting that Al release increased when acid or alkali solutions were added. In non- 

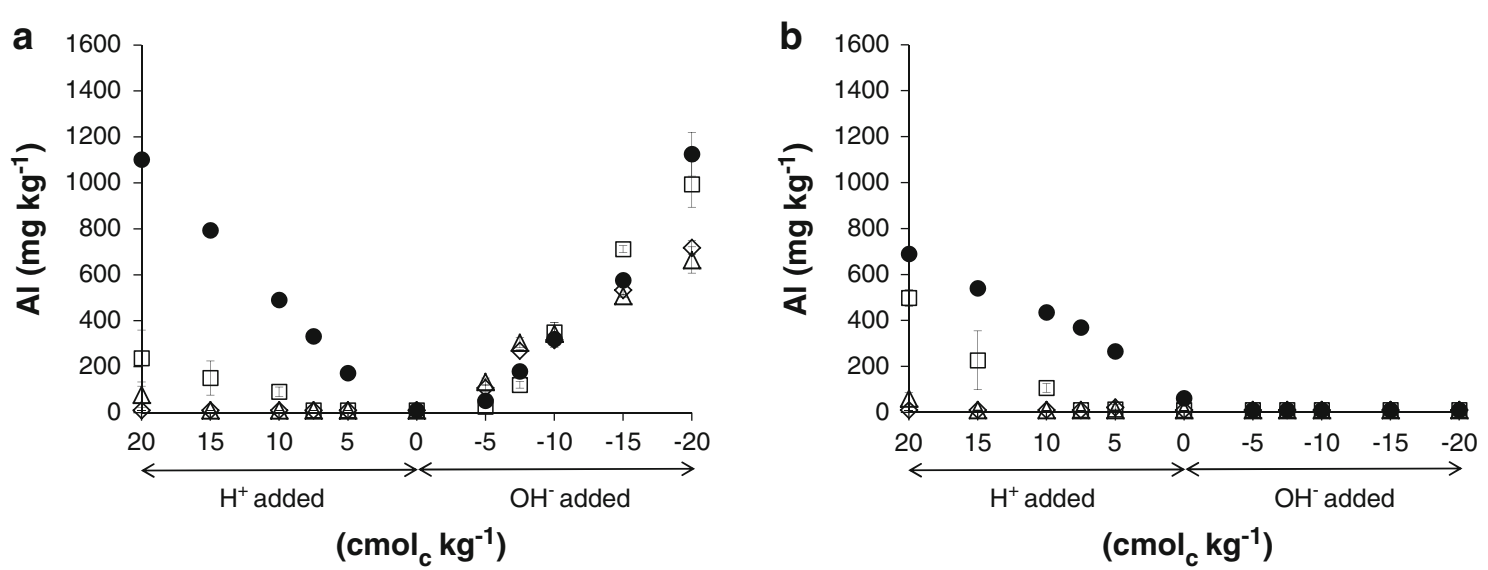

Fig. 4 Changes in $\mathrm{Al}$ release as a function of the addition of $\mathrm{HNO}_{3}$ or $\mathrm{NaOH}$ solutions to samples of a vineyard soil (a) and mine soil (b) nonamended (filled circles) and amended with 12 (squares), 24 (triangles) and 48 (diamonds) $\mathrm{Mg} \mathrm{ha}^{-1}$ of CMS

amended soil $\mathrm{B}, \mathrm{Al}$ only was released when soil samples were treated with acid solutions (Fig. 4). The release of Al observed in both soils after acid treatments is consistent with the well-known role of $\mathrm{Al}$ compounds in soil solid phase as dominant source of buffering capacity in acid soils (Mulder and Stein 1994; Lazerte and Findeis 1995). The different behaviour observed after alkali treatments could be related to the different $\mathrm{pH}$ values reached in soil A or B after application of basic solutions. Thus, soil A reached pH 8 when $0.02 \mathrm{M} \mathrm{NaOH}$ solution was added being seven in the case of soil B. Since Al precipitates at $\mathrm{pH}$ between 5 and $7, \mathrm{pH}$ values should be higher than seven to be released by dissolution of Al-bearing solid phases, which could occur in soil A but not in soil B. Crushed mussel shell additions also diminished clearly the amount of $\mathrm{Al}$ released from both soils under acid conditions (Fig. 4) and thus, the average of $\mathrm{Al}$ liberated when both soils were treated with the most acid solution was about $10 \mathrm{mg} \mathrm{kg}^{-1}$ for CMS additions of $48 \mathrm{Mg} \mathrm{ha}^{-1}$ for both soils (Fig. 4). No effects of CMS addition were observed in $\mathrm{Al}$ released from soil $\mathrm{B}$ when control or soil/CMS mixtures were treated with alkali solutions. However, Al liberation was slightly lower in CMS amended samples at such $\mathrm{pH}$ values (Fig. 4). The liberation of $\mathrm{Al}$ from soil under alkali treatments was also accompanied by the release of OMd (see Table 2), suggesting that Al-humus complexes could be dissolved due to the action of alkali solutions. This hypothesis is consistent with findings of Takahashi et al. (2006), who observed a significant reduction in organically complexed $\mathrm{Al}$ after liming in acid soils.

\section{Copper fractionation}

The results of $\mathrm{Cu}$ fractionation for the various residues of soil/CMS mixtures treated with acid $\left(0.02 \mathrm{M} \mathrm{HNO}_{3}\right)$, base
(0.02 $\mathrm{M} \mathrm{NaOH)}$ and without acid or base (0.05 M NaNO3) were shown in Table 3. Non-amended samples of soil A showed a significant decrease in $\mathrm{Cu}$ content of the ASF fraction (LSD, $p<0.001$ ) from values of $72 \pm 3 \mathrm{mg} \mathrm{kg}^{-1}$ for samples without acid or base treatment to $31 \pm 3 \mathrm{mg} \mathrm{kg}^{-1}$ for those treated with acid. However, the decrease in $\mathrm{Cu}$ content from ASF fractions was less pronounced (and not significant, LSD, $p<0.065$ ) for alkalitreated samples which showed a mean value of $62 \pm 1 \mathrm{mg} \mathrm{kg}^{-1}$ (Table 3). A similar behaviour was observed for $\mathrm{Cu}$ content in the RF fraction, which showed a significant decrease from $43 \pm 2 \mathrm{mg} \mathrm{kg}^{-1}$ for the untreated samples $\left(0.05 \mathrm{M} \mathrm{NaNO}_{3}\right)$ to $27 \pm 2 \mathrm{mg} \mathrm{kg}^{-1}$ for the acid-treated samples (LSD, $p<0.039$ ), although $\mathrm{Cu}$ diminution in $\mathrm{RF}$ fraction treated with alkali solution $\left(30 \pm 1 \mathrm{mg} \mathrm{kg}^{-1}\right)$ did not differ significantly from untreated samples (LSD, $p<0.080$ ). As regards $\mathrm{Cu}$ content in the $\mathrm{OF}$ fraction, there were no significant differences (LSD) between the untreated and the acid-treated samples ( $33 \pm 2$ vs. $\left.37 \pm 4 \mathrm{mg} \mathrm{kg}^{-1}\right)$, whereas significant differences between the not treated and the alkali-treated samples (LSD, $p<0.022$ ) were observed (Table 3). Regarding the most abundant $\mathrm{Cu}$ fraction, REF, there were no significant differences between the untreated and the acid-treated samples (LSD, $p<0.199$ ) which could be due to the high variability observed within samples. However, a significant decrease in $\mathrm{Cu}$ content in REF fraction was shown by alkali treated samples of soil $\mathrm{A}$, whose $\mathrm{Cu}$ average in this fraction was significantly lower than for not treated samples (LSD, $p<0.046)$. These results suggest that for non-amended samples of A soil treated with $0.02 \mathrm{M} \mathrm{HNO}_{3}$ solution, the $\mathrm{Cu}$ release took place mainly from labile fractions such as ASF and RF fractions. This may be inferred taking into consideration the decrease of $\mathrm{Cu}$ content observed in these fractions when they were 
Table 3 Mean and standard error values (in $\mathrm{mg} \mathrm{kg}^{-1}$ ) of $\mathrm{Cu}$ distribution in amended and non-amended samples $\left(\mathrm{A}_{0}\right.$ and $\mathrm{B}_{0}$ : no CMS; $\mathrm{A}_{12}$ and $\mathrm{B}_{12}: 12 \mathrm{Mg} \mathrm{ha}^{-1}$ of CMS; $\mathrm{A}_{24}$ and $\mathrm{B}_{24}: 24 \mathrm{Mg} \mathrm{ha}^{-1}$ of CMS; $\mathrm{A}_{48}$ and $\mathrm{B}_{48}: 48 \mathrm{Mg}^{-1}$ of CMS) for vineyard soil (A) and mine soil (B) as a function of the amount of acid or base added

\begin{tabular}{|c|c|c|c|c|c|c|c|c|c|c|c|c|}
\hline \multirow[t]{3}{*}{ Sample } & \multicolumn{12}{|c|}{ Acid or base added } \\
\hline & \multicolumn{4}{|c|}{$0.02 \mathrm{M} \mathrm{HNO}_{3}$} & \multicolumn{4}{|l|}{ None } & \multicolumn{4}{|c|}{$0.02 \mathrm{M} \mathrm{NaOH}$} \\
\hline & ASF & $\mathrm{RF}$ & $\mathrm{OF}$ & REF & ASF & $\mathrm{RF}$ & $\mathrm{OF}$ & REF & ASF & $\mathrm{RF}$ & $\mathrm{OF}$ & REF \\
\hline \multicolumn{13}{|l|}{ A } \\
\hline $\mathrm{A}_{0}$ & $31 \pm 3$ & $27 \pm 2$ & $37 \pm 4$ & $138 \pm 18$ & $72 \pm 3$ & $43 \pm 2$ & $33 \pm 2$ & $162 \pm 13$ & $62 \pm 1$ & $30 \pm 1$ & $23 \pm 1$ & $89 \pm 2$ \\
\hline $\mathrm{A}_{12}$ & $56 \pm 5^{*}$ & $36 \pm 2$ & $30 \pm 3$ & $128 \pm 20$ & $75 \pm 3$ & $46 \pm 0$ & $37 \pm 3$ & $166 \pm 2$ & $66 \pm 2$ & $35 \pm 3$ & $29 \pm 4$ & $114 \pm 12$ \\
\hline $\mathrm{A}_{24}$ & $69 \pm 3 *$ & $38 \pm 2$ & $27 \pm 1$ & $156 \pm 13$ & $78 \pm 2$ & $51 \pm 1^{*}$ & $42 \pm 3$ & $190 \pm 8^{*}$ & $65 \pm 5$ & $40 \pm 1$ & $28 \pm 5$ & $122 \pm 23$ \\
\hline $\mathrm{A}_{48}$ & $67 \pm 3^{*}$ & $51 \pm 5^{*}$ & $39 \pm 3$ & $160 \pm 14$ & $68 \pm 1$ & $53 \pm 0 *$ & $45 \pm 1$ & $188 \pm 1^{*}$ & $55 \pm 1$ & $38 \pm 1$ & $18 \pm 1$ & $115 \pm 1$ \\
\hline \multicolumn{13}{|l|}{ B } \\
\hline $\mathrm{B}_{0}$ & $4 \pm 0$ & $4 \pm 0$ & $114 \pm 10$ & $338 \pm 11$ & $7 \pm 0$ & $6 \pm 0$ & $128 \pm 2$ & $342 \pm 4$ & $5 \pm 0$ & $8 \pm 0$ & $88 \pm 7$ & $433 \pm 16$ \\
\hline $\mathrm{B}_{12}$ & $4 \pm 0$ & $4 \pm 0$ & $120 \pm 2$ & $379 \pm 23$ & $5 \pm 1$ & $7 \pm 0$ & $108 \pm 18$ & $407 \pm 16$ & $4 \pm 0$ & $8 \pm 0$ & $113 \pm 16$ & $419 \pm 12$ \\
\hline $\mathrm{B}_{24}$ & $5 \pm 0$ & $5 \pm 1$ & $118 \pm 6$ & $360 \pm 17$ & $5 \pm 0$ & $7 \pm 0$ & $92 \pm 10$ & $396 \pm 14$ & $4 \pm 0$ & $8 \pm 0$ & $113 \pm 10$ & $383 \pm 5$ \\
\hline $\mathrm{B}_{48}$ & $4 \pm 0$ & $8 \pm 0$ & $70 \pm 2 *$ & $445 \pm 8 *$ & $4 \pm 0$ & $7 \pm 0$ & $76 \pm 21$ & $449 \pm 16$ & $4 \pm 0$ & $8 \pm 0$ & $47 \pm 1$ & $436 \pm 14$ \\
\hline
\end{tabular}

* Significant differences with the control sample (A0 and B0), as per Dunnet test $(p<0.05)$

compared to those samples non-acid or alkali treated $(0.05 \mathrm{M} \mathrm{NaNO}$ ). However in the case of soil $\mathrm{A}$ nonamended samples treated with $0.02 \mathrm{M} \mathrm{NaOH}$, the $\mathrm{Cu}$ liberation seemed to derive from the less mobile fractions such as $\mathrm{OF}$ and REF.

The statistic test of Dunnet was used to compare nonamended soils and amended soils with the various CMS doses. In soil A, regarding the ASF fraction in the acidtreated samples, the addition of all CMS doses resulted in a significant increase $(p<0.05)$ of $\mathrm{Cu}$ content in this fraction (from $31 \pm 3 \mathrm{mg} \mathrm{kg}^{-1}$ till values ranged from 56 to $69 \mathrm{mg} \mathrm{kg}{ }^{-1}$; Table 3). The $\mathrm{Cu}$ content in $\mathrm{RF}$ fraction of samples treated with acid also showed significant differences, but only at the highest CMS dose. Copper content in $\mathrm{OF}$ and REF fractions did not show significant differences for samples treated with acid at any CMS dose (Table 3). For samples of soil A treated with $0.05 \mathrm{M} \mathrm{NaNO}_{3}$ (no acid or base added), only $\mathrm{Cu}$ contents for RF and REF fractions showed a significant increase regarding non-amended samples when CMS addition was 24 or $48 \mathrm{Mg} \mathrm{ha}^{-1}$ (Table 3). Samples of A soil treated with alkali solutions did not show significant differences for any $\mathrm{Cu}$ fraction or CMS dose.

In samples from soil $\mathrm{B}$, either for untreated, acid and alkali treated, $\mathrm{Cu}$ content in ASF and RF fractions showed low values that ranged from 4 to $8 \mathrm{mg} \mathrm{kg}^{-1}$ (Table 3). This suggests that $\mathrm{pH}$ treatments and CMS addition did not influence $\mathrm{Cu}$ distribution in these fractions. However, $\mathrm{Cu}$ content in $\mathrm{OF}$ decreased significantly in acid treated samples amended with the highest CMS dose $\left(70 \pm 2 \mathrm{mg} \mathrm{kg}^{-1}\right)$ comparing to non-amended samples
(114 $\pm 10 \mathrm{mg} \mathrm{kg}^{-1}$; Table 3$)$. On the contrary, a significant increase in $\mathrm{Cu}$ content of the REF fraction was observed after comparing the $\mathrm{Cu}$ values in non-amended soil $\left(338 \pm 11 \mathrm{mg} \mathrm{kg}^{-1}\right)$ and that amended with $48 \mathrm{Mg} \mathrm{ha}^{-1}$ CMA (445 $\left.\pm 8 \mathrm{mg} \mathrm{kg}^{-1}\right)$. Although it was not statistically significant, for untreated samples $(0.05 \mathrm{M}$ $\mathrm{NaNO}_{3}$ solution) there is an apparent trend to diminution of $\mathrm{Cu}$ contents in the OF fraction with the increase in the CMS dose (from $128 \pm 2 \mathrm{mg} \mathrm{kg}^{-1}$ at no CMS addition to $76 \pm 21 \mathrm{mg} \mathrm{kg}^{-1}$ at $48 \mathrm{Mg} \mathrm{ha}^{-1} \mathrm{CMS}$, Table 3). A similar result was found for alkali-treated samples, although in this case the highest values of $\mathrm{Cu}$ in the $\mathrm{OF}$ fraction occurred in samples amended with 12 and $24 \mathrm{Mg} \mathrm{ha}^{-1}$ (Table 3). The addition of CMS did not constitute a significant factor of variation in $\mathrm{Cu}$ content for the $\mathrm{REF}$ fractions, ranging from 342 to $449 \mathrm{mg} \mathrm{kg}^{-1}$ for untreated samples and from 383 to $436 \mathrm{mg} \mathrm{kg}^{-1}$ for alkali treated samples (Table 3).

The results from $\mathrm{Cu}$ fractionation in soil $\mathrm{B}$ revealed that $\mathrm{Cu}$ distribution was very similar in all cases. This was an expected result bearing in mind that $\mathrm{Cu}$ release was limited to acid $\mathrm{pH}$ values, either in control samples (no CMS added) or in samples amended with low-CMS doses. In all cases, dissolved $\mathrm{Cu}$ was always lower than $5 \%$ of the total $\mathrm{Cu}$ content in the control sample.

\section{$\mathrm{Cu}$ desorption kinetics}

Figure 5 shows the results of $\mathrm{Cu}$ release kinetics for the control samples (A0, without CMS addition) compared with those treated with the highest CMS dose (A48, 

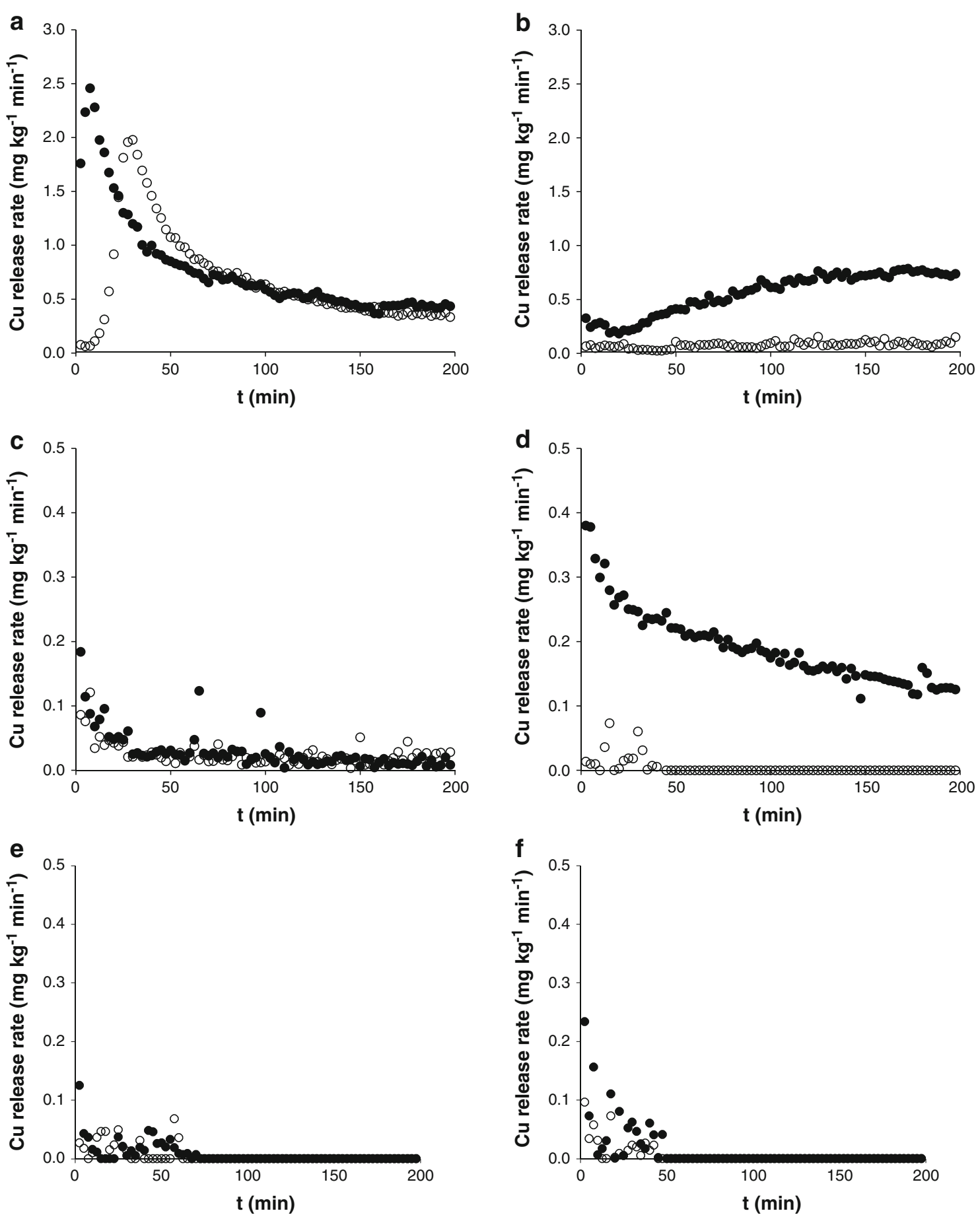

Fig. 5 Changes in $\mathrm{Cu}$ release rates in vineyard soil samples $(\mathbf{a}, \mathbf{c}, \mathbf{e})$ and mine soil samples $(\mathbf{b}, \mathbf{d}, \mathbf{f})$ without CMS addition (filled circles) and with $48 \mathrm{Mg} \mathrm{ha}^{-1}$ of CMS (empty circles) at inflow solution $\mathrm{pH} 3$ (top); $\mathrm{pH} 5$ (middle) and $\mathrm{pH} 7$ (bottom)

$48 \mathrm{Mg} \mathrm{ha}^{-1}$ of $\left.\mathrm{CMS}\right)$. These results showed that the $\mathrm{Cu}$ release rates were highly affected by $\mathrm{pH}$ values, and diminished as the $\mathrm{pH}$ of the inflow solution increased. Referred to the vineyard soil at $\mathrm{pH} 3$, A0 soil sample showed a value of $2.46 \mathrm{mg} \mathrm{kg}^{-1} \mathrm{~min}^{-1}$ as maximum release velocity, while the amended sample (A48) showed a value of $1.98 \mathrm{mg} \mathrm{kg}^{-1} \mathrm{~min}^{-1}$. The A0 sample reached its maximum release velocity faster $(7.5 \mathrm{~min})$ than the 
A48 (30 min). The addition of CMS to soil A resulted in a decrease of $12 \%$ in the average $\mathrm{Cu}$ release velocity during the experiment, whereas the maximum $\mathrm{Cu}$ release velocity measured during the experiments suffered a $19 \%$ diminution. The $\mathrm{Cu}$ release velocities vary notably with time. Between the beginning of the experiment and $22.5 \mathrm{~min}, \mathrm{Cu}$ release velocities are much higher when CMS is absent than in its presence, while between 22.5 and $75 \mathrm{~min} \mathrm{Cu}$ release velocities are higher in the presence of CMS than in its absence and, finally, since $75 \mathrm{~min}$ until the end of the experiment, $\mathrm{Cu}$ release velocities are very similar with or without CMS addition. This means that the addition of CMS was very effective diminishing $\mathrm{Cu}$ release during first $22.5 \mathrm{~min}$ of the experiment $(\mathrm{Cu}$ release diminishes $86 \%$ in this lag), while for times over $22.5 \mathrm{~min}$ the percentage reduction was lower. When this experiment was carried out with mine soil (B), the results obtained were very different. The B0 sample (no CMS addition) showed a slight increase in the $\mathrm{Cu}$ release velocity with time, reaching $0.80 \mathrm{mg} \mathrm{kg}^{-1} \min ^{-1}$ as a maximum, while the $\mathrm{Cu}$ release velocity was very low for the B48 sample, reaching $0.15 \mathrm{mg} \mathrm{kg}^{-1} \min ^{-1}$ as a maximum (Fig. 5), meaning a $86 \%$ of $\mathrm{Cu}$ desorption rate reduction. These differences between soil $\mathrm{A}$ and $\mathrm{B}$ in $\mathrm{Cu}$ release rates would be explained by the particular $\mathrm{Cu}$ distribution in each one. Although the mine soil (B) has more total $\mathrm{Cu}$, the vineyard soil (A) had higher $\mathrm{Cu}$ contents in the most labile fractions (ASF and RF) which favoured its release as a response to the addition of an acid solution ( $\mathrm{pH} 3$ ). Furthermore, the different mineral composition of both soils could affect the potential $\mathrm{Cu}$ retention due to the aragonite into the shell, as was suggested by the study of Köhler et al. (2007) on the removal of cadmium by aragonite shells and the influence of other divalent cations.

At $\mathrm{pH} 5$, the $\mathrm{Cu}$ release velocities were very low in both soils. In soil $\mathrm{A}$, the maximum velocities reached 0.18 and $0.12 \mathrm{mg} \mathrm{kg}^{-1} \mathrm{~min}^{-1}$ for the A0 and A48 samples, respectively. In soil $\mathrm{B}$, the $\mathrm{Cu}$ release velocity diminished with time from 0.38 to $0.15 \mathrm{mg} \mathrm{kg}^{-1} \mathrm{~min}^{-1}$ in the B0 sample, whereas the velocity decreased up to $98 \%$ in the B48 sample with B0 being very low during the whole experiment (Fig. 5). When the $\mathrm{pH}$ of inflow solution was five, the differences in soil $\mathrm{A}$ and soil $\mathrm{B}$ would be explained by soil $\mathrm{pH}$. The vineyard soil had an average $\mathrm{pH}$ value of 5.0 in the outflow solution, while this value was 4.0 in the case of the mine soil due to its higher natural acidity. Consequently in the absence of high acid load, the mine soil will release more $\mathrm{Cu}$ than the vineyard soil (38 and $7 \mathrm{mg} \mathrm{kg}^{-1}$, respectively). It is well known that $\mathrm{Cu}$ retention in the soil increased as soil pH decreased (Fernández-Calviño et al. 2010b).
At $\mathrm{pH} 7$, the $\mathrm{Cu}$ release velocities were very low for all samples without CMS addition (0.00-0.13 $\mathrm{mg} \mathrm{kg}^{-1} \mathrm{~min}^{-1}$ for soil $\mathrm{A}$ and $0.00-0.23 \mathrm{mg} \mathrm{kg}^{-1} \mathrm{~min}^{-1}$ for soil $\mathrm{B}$ ), and there were no significant differences between control samples and those amended with $48 \mathrm{Mg} \mathrm{ha}^{-1}$ (Fig. 5). The $\mathrm{Cu}$ bonds to the soil particles could be very high at this $\mathrm{pH}$ value, resulting in a high $\mathrm{Cu}$ retention in the soil. However, this $\mathrm{pH}$ value is not enough to release $\mathrm{Cu}$ from the soil by means of organic matter dissolution in high proportions (Fernández-Calviño et al. 2008).

\section{Conclusion}

The addition of crushed mussel shell to $\mathrm{Cu}$-rich acid soils provides them with a substantial buffer capacity which keeps $\mathrm{pH}$ values near neutrality even after extreme acid events. This makes CMS a suitable material to reduce the acidity of acid soils, being this application very interesting especially due to its low cost. This buffer capacity supplied by CMS is mainly due to the dissolution of $\mathrm{Ca}$ carbonates from mussel shell. Moreover, the addition of CMS to both vineyard and mine soils caused a significant decrease in $\mathrm{Cu}$ release when they were experimentally acidified. However, under alkali treatments, $\mathrm{Cu}$ liberation increased in CMS amended soil A (vineyard) whereas the level of this metal released by CMS amended soil B (mine) remains near the detection limit. This difference was narrowly associated to the distinct $\mathrm{Cu}$ distribution in the solid phase of both soils, mainly in terms of organically complexed $\mathrm{Cu}$.

Copper released after acid treatment of non-amended samples of soil A derived from ASF and RF fractions. In the case of samples treated with alkali solutions, mobilized $\mathrm{Cu}$ is originated from $\mathrm{OF}$ and REF fractions. An increase in $\mathrm{Cu}$ content corresponding to ASF and FR fractions was found for acid treated CMS amended samples of soil A. No influences of $\mathrm{pH}$ treatment and CMS addition in ASF and $\mathrm{RF} \mathrm{Cu}$ fractions were found for soil $\mathrm{B}$, although a decrease in the OF fraction was observed for acid treated samples amended with $48 \mathrm{Mg} \mathrm{ha}^{-1}$.

The presence of CMS significantly diminished the mean and maximum $\mathrm{Cu}$ release rate values at acid $\mathrm{pH}$ in both soils. When the inflow solution $\mathrm{pH}$ was 5 , the mine soil showed a drastic $\mathrm{Cu}$ release rate reduction upon CMS addition, whereas no significant effects of CMS addition were found in $\mathrm{Cu}$ release rates in the vineyard soil. When $\mathrm{pH}$ of inflow solution was seven, $\mathrm{Cu}$ released rates were very low, and no significant effects of CMS addition were found.

The obtained results revealed that, the addition of CMS to the soils as amended would diminish the risks of 
environmental damage (namely those related to $\mathrm{Cu}$ ) when an acidification or an acid pollution event takes place. Particularly on acid vineyard soils, widely spread in Galicia, the addition of CMS in order to prevent an excessive $\mathrm{Cu}$ uptake by plants would be recommended.

Acknowledgments This work was funded by the Xunta de Galicia (Government of Galicia, Spain) within the INCITE program (Ref. 09MDS013291PR). David Fernández-Calviño holds a postdoctoral contract into the Ángeles Alvariño program (Consellería de Innovación e Industria, Xunta de Galicia).

\section{References}

Abeynaike A, Wang L, Jones MI, Patterson DA (2011) Pyrolysed powdered mussel shells for eutrophication control: effect of particle size and powder concentration on the mechanism and extent of phosphate removal. Asia-Pac J Chem Eng 6:231-243

Álvarez E, Fernández-Sanjurjo M, Otero XL, Macías F (2011) Aluminum speciation in the bulk and rhizospheric soil solution of the species colonizing an abandoned copper mine in Galicia (NW Spain). J Soils Sediment 11:221-230

Bailey SE, Olin TJ, Bricka RM, Adrian D (1999) A review of potentially low-cost sorbents for heavy metals. Wat Res 33:2469-2479

Barros MC, Magán A, Valiño S, Bello PM, Casares JJ, Blanco JM (2009) Identification of best available techniques in the seafood industry: a case study. J Clean Prod 17:391-399

Bertsch PM, Bloom PR (1996) Aluminum. In: Sparks DL (ed) Methods of soil analysis. Part 3-Chemical methods. SSSA Book Series:5. SSSA and ASA: Madison, WI

Caballero G, Garza MD, Varela M (2009) The institutional foundations of economic performance of mussel production: the Spanish case of the Galician floating raft culture. Mar Policy 33:288-296

Cubillas P, Kfhlerb S, Prieto M, ChaRratb C, Oelkers EH (2005a) Experimental determination of the dissolution rates of calcite, aragonite, and bivalves. Chem Geol 216:59-77

Cubillas P, Köhler S, Prieto M, Causserand C, Oelkers EH (2005b) How do mineral coatings affect dissolution rates? An experimental study of coupled $\mathrm{CaCO}_{3}$ dissolution- $\mathrm{CdCO}_{3}$ precipitation. Geochim Cosmochim Acta 69:5459-5476

Currie JA, Harrison NR, Wang L, Jones MI, Brooks MS (2007) A preliminary study of processing seafood shells for eutrophication control. Asia-Pac J Chem Eng 2:460-467

Dizadji N, Abootalebi Anaraki N, Nouri N (2011) Adsorption of chromiun and copper in aqueous solutions using tea residi. Int $\mathrm{J}$ Environ Sci Tech 8:631-638

Fernández-Calviño D, Pateiro-Moure M, López-Periago E, AriasEstévez M, Nóvoa-Muñoz JC (2008) Copper distribution and acid-base mobilization in vineyard soils and sediments from Galicia (NW Spain). Eur J Soil Sci 59:315-326

Fernández-Calviño D, Nóvoa-Muñoz JC, Díaz-Raviña M, AriasEstévez M (2009a) Copper accumulation and fractionation in vineyard soils from temperate humid zone (NW Iberian Peninsula). Geoderma 153:119-129

Fernández-Calviño D, Pérez-Novo C, Nóvoa-Muñoz JC, AriasEstévez M (2009b) Copper fractionation and release from soils devoted to different crops. J Hazard Mater 167:797-802

Fernández-Calviño D, Pérez-Novo C, Bermúdez-Couso A, LópezPeriago E, Arias-Estévez M (2010a) Batch and stirred flow reactor experiments on $\mathrm{Zn}$ sorption in acid soils. $\mathrm{Cu}$ Compet Geodema 159:417-424

Fernández-Calviño D, Soler-Rovira $\mathrm{P}$, Polo A, Arias-Estévez M, Plaza C (2010b) Influence of humified organic matter on copper behavior in acid polluted soils. Environ Pollut 158:3634-3641

Gee GW, Bauder JW (1986) Particle-size analysis. In: Klute A (ed) Methods of soil analysis. Part 1-Physical and mineralogical methods. 2nd edn. SSSA Book Series:5. SSSA and ASA: Madison, WI

Kitano Y, Kanamori N, Yoshioka S (1976) Adsorption of zinc and copper ions on calcite and aragonite and its influence on the transformation of aragonite to calcite. Geochem J 10:175-179

Köhler S, Cubillas P, Rodríguez-Blanco JD, Bauer C, Prieto M (2007) Removal of cadmium from wastewaters by aragonite shells and the influence of other divalent cations. Environ Sci Technol 41:112-118

Lazerte BD, Findeis J (1995) The relative importance of oxalate and pyrophosphate extractable aluminum to the acidic leaching of aluminum in podzol B horizons from the Precambrian Shield, Ontario Canada. Can J Soil Sci 75:43-54

López-Periago JE, Arias M, Nóvoa-Muñoz JC, Fernández-Calviño D, Soto B, Pérez-Novo C, Simal-Gándara J (2008) Copper retention kinetics in acid soils. Soil Sci Soc Am J 72:63-72

Mulder J, Stein A (1994) The solubility of aluminum in acidic forest soils: long-term changes due to acid deposition. Geochim Cosmochim Acta 58:85-94

Nóvoa-Muñoz JC, García-Rodeja Gayoso E (2007) Modification of soil solid Al phases during an extreme experimental acidification of A horizons of forest soils from southwest Europe. Water Air Soil Pollut Focus 7:235-239

Peña-Rodríguez S, Fernández-Calviño D, Nóvoa-Muñoz JC, AriasEstévez M, Núñez-Delgado A, Fernández-Sanjurjo MJ, ÁlvarezRodríguez E (2010) Kinetics of $\mathrm{Hg}$ (II) adsorption and desorption in calcined mussel shells. J Hazard Mater 180:622-627

Prieto M, Cubillas P, Fernández-González A (2003) Uptake of dissolved $\mathrm{Cd}$ by biogenic and abiogenic aragonite: a comparison with sorption onto calcite. Geochim Cosmochim Acta 67:3859-3869

Rauret G, López-Sánchez JF, Sahuquillo A, Davidson C, Ure A, Quevauviller PhM (1999) Improvement of the BCR three step sequential extraction procedure prior to the certification of new sediment and soil reference materials. J Environ Monit $1: 57-61$

Sakulkhaemaruethai S, Duangduen C, Pivsa-Art W, Pivsa-Art S (2010) Fabrication of composite material from sea mussel shells and white clay as a versatile sorbent. Energy Res J 1:78-81

Simonsson M, Berggern D (1998) Aluminium solubility related to secondary solid phases in upper B horizons with spodic characteristics. Eur J Soil Sci 49:317-326

Sumner ME, Miller WP (1996) Cation exchange capacity and exchange coefficients. In: Sparks DL (ed) Methods of soil analysis. Part 3-Chemical methods. SSSA Book Series:5. SSSA and ASA: Madison, WI

Takahashi T, Ikeda Y, Fujita K, Nanzyo M (2006) Effect of liming on organically complexed aluminum of nonallophanic Andosols from northeastern Japan. Geoderma 130:26-34

Ure AM, Quevauviller P, Muntau H, Griepink B (1993) Speciation of heavy metals in soils and sediments. An account of the improvement and harmonization of extraction techniques undertaken under the auspices of the BCR of the Commission of the European Communities. Int $\mathrm{J}$ Environ Anal Chem $51: 135-151$

Yagasaki Y, Mulder J, Okazaki M (2006) Comparing the activity of aluminum in two B horizons developed from volcanic ash deposits in Japan, dominated by short-range ordered 
aluminosilicates and crystalline clay minerals, respectively. Geochim Cosmochim Acta 70:147-163

Yin Y, Allen HE, Huang CP, Sparks DL, Sanders PF (1997) Kinetics of mercury(II) adsorption and desorption on soil. Environ Sci Technol 31:496-503
Zvinowanda CM, Okonkwo JO, Shabalala PN, Agyel NM (2009) A novel adsorbent for heavy metal remediation in aqueous environments. Int J Environ Sci Tech 6:425-434 